\author{
Jurnal E-KOMTEK (Elektro-Komputer-Teknik) \\ Vol. 4, No. 1 (2020) pp. 75-90 \\ https://jurnal.politeknik-kebumen.ac.id/index.php/E-KOMTEK \\ p-ISSN : 2580-3719 e-ISSN : 2622-3066
}

\title{
Pengembangan Web Service Digital Assessment Test of English For International Communication (TOEIC)
}

\author{
Sopingi ${ }^{1 *}$, Ratini Setyowati ${ }^{2}$, Singgih Purnomo ${ }^{3}$ \\ 1Sistem Informasi, Universitas Duta Bangsa, Surakarta, Indonesia, 57154 \\ ${ }^{2}$ Rekam Medik dan Informasi Kesehatan, Universitas Duta Bangsa, Surakarta, Indonesia, 57154 \\ 3Sistem Informasi, Universitas Duta Bangsa, Surakarta, Indonesia, 57154 \\ *E-mail : sopingi@udb.ac.id \\ Doi : https://doi.org/10.37339/e-komtek.v4i1.232
}

Diterbitkan oleh Politeknik Dharma Patria Kebumen

\section{Info Artikel \\ Diterima : \\ 30-05-2020 \\ Diperbaiki : \\ 07-06-2020 \\ Disetujui : \\ 17-06-2020}

\begin{abstract}
ABSTRAK
Test of English for International Communication (TOEIC) adalah tes standar internasional kemahiran bahasa Inggris untuk penutur asing. Selama ini lembaga pendidikan bahasa inggris menggunakan kertas dan perangkat audio player untuk melaksanakan ujian TOEIC, ada juga lembaga yang sudah menggunakan aplikasi tetapi masih bersifat sistem terpusat dan apabila terjadi gangguan pada server maka seluruh aktivitas akan terganggu. Penelitian ini membahas pengembangan web service sebagai jembatan komunikasi data antara basis data dengan aplikasi ujian atau assessment TOEIC yang ada di sisi client dengan pendekatan Service Oriented Architecture (SOA) dan Prototipe. Hasil penelitian berupa aplikasi web service yang di-install di cloud server dan local server serta aplikasi desktop sebagai client yang digunakan untuk pelaksanaan assessment. Hasil pengujian beta menunjukan aplikasi digital assessment TOEIC layak untuk digunakan sedangkan pengujian terhadap performance memiliki response time paling lama $120 \mathrm{~ms}$ dan paling cepat $20 \mathrm{~ms}$.
\end{abstract}

Kata Kunci: Web Service; Digital Assessment; TOEIC; SOA; Prototype

\begin{abstract}
The Test of English for International Communication (TOEIC) is an international standard test of English language proficiency for foreign speakers. During this English language education institutions use paper and audio player devices to carry out the TOEIC exam, there are also institutions that have used the application but are still centralized and if there is interference on the server then all activities will be disrupted. This study discusses the development of web services as a bridge of data communication between the database and the TOEIC assessment or assessment application on the client side with the Service Oriented Architecture (SOA) and Prototype approaches. The results of the research are web service applications that are installed on cloud servers and local servers and desktop applications as clients that are used for conducting assessments. Beta test results show that the TOEIC digital assessment application is suitable for use while the performance test has a maximum response time of $120 \mathrm{~ms}$ and a maximum of $20 \mathrm{~ms}$. Keywords: Web Service; Digital Assessment; TOEIC; SOA; Prototype
\end{abstract}




\section{PENDAHULUAN}

Sekolah Test of English for International Communication atau biasa disingkat TOEIC adalah tes standar internasional kemahiran bahasa Inggris untuk penutur asing. TOEIC bertujuan untuk mengukur kemampuan bahasa Inggris sehari-hari dari orang yang bekerja di lingkungan internasional. Selama ini lembaga pendidikan bahasa inggris menggunakan kertas dan perangkat audio player untuk melaksanakan ujian TOEIC sehingga membutuhkan tenaga dan waktu lebih banyak untuk pelaksanaan ujian ataupun koreksi hasil ujian. Selain media kertas juga sudah ada aplikasi yang digunakan untuk ujian TOEIC tetapi masih bersifat sistem terpusat yaitu aplikasi dan basis data terdapat dalam satu komputer yang sama. Sistem terpusat memiliki kelemahan yaitu harus memiliki spesifikasi server yang baik dan apabila terjadi gangguan pada server maka seluruh aktivitas akan terganggu [1]. Aplikasi seharusnya memiliki performance yang baik dan dapat diterapkan dengan berbagai arsitektur jaringan, sistem operasi, platform aplikasi dan perangkat keras [2].

Penelitian terdahulu dengan judul "Sistem Informasi Manajemen Tes TOEIC" oleh Darma Putra Pratama, dkk [3], dengan metode waterfall dan menggunakan framework Codeigniter telah dihasilkan aplikasi tes TOEIC berbasis web dan android. Pengujian menggunakan metode kuisioner melibatkan 10 pengguna dengan tingkat kepuasan 83.3\%. Kelemahan aplikasi adalah belum mampu melakukan kontroling Listening Test, peserta ujian masih bisa melakukan pause bahkan mengunduh file audio. Penelitian yang dilakukan oleh Darma Putra Pratama, dkk belum melakukan pengujian terhadap performance aplikasi yang dibuat.

Penelitian dengan judul "Pengembangan Aplikasi Listening Test Berbasis Android" oleh Rokhimatul Wakhidah, dkk [4], metode yang digunakan adalah Research and Development. Pengujian yang dilakukan adalah validasi ahli media dengan nilai 68,75\% dan kuisioner 11 pengguna dengan nilai 92\%. Aplikasi yang dihasilkan berupa prototipe dan saat pelaksanaan listening test, audio harus dijalankan secara manual. Penelitian yang dilakukan oleh Rokhimatul Wakhidah, dkk belum diujikan dengan jumlah pengguna yang banyak dan tidak diketahui tingkat performance.

Penelitian dengan judul "Perancangan Aplikasi Mobile Learning Test of English For International Communication (TOEIC) Simulation pada Smartphone Berbasis Android" oleh Yayang Fitria Chandra, dkk [5] menggunakan teknologi web service dalam komunikasi data antara aplikasi dan basis data, namun belum seluruh data disimpan dalam basis data dan aplikasi yang dihasilkan baru sebatas simulasi. 
Berdasarkan penelitian terdahulu penulis dalam penelitian ini membahas pengembangan web service sebagai jembatan komunikasi data antara basis data dengan aplikasi ujian atau assessment TOEIC yang ada di sisi client. Web service mampu menangani komunikasi antara aplikasi yang berbeda platform, sistem operasi atapun bahasa pemrograman yang digunakan [6]. Layanan yang tersedia dalam web service yang dikembangkan adalah manajemen soal yang terenkripsi, manajemen sesi dan peserta, monitoring jalannya assessment dan melakukan koreksi untuk perhitungan score. Penulis melakukan pengujian terhadap performance aplikasi sehingga diketahui tingkat kehandalanya dengan mengukur nilai response time pada setiap request yang terjadi. Untuk mendapatkan nilai performance yang baik maka web service dikembangkan dengan metode Representational State Transfer (REST) karena memiliki nilai response time terbaik dalam proses integrasi data [7].

Tujuan yang ingin penulis capai adalah dihasilkan aplikasi yang layak untuk digunakan sebagai digital assessment TOEIC serta diketahuinya performance aplikasi berdasarkan nilai response time. Untuk mencapai tujuan tersebut penulis menggunakan kombinasi metode dalam melakukan penelitian ini yaitu menggunakan metode pendekatan Service Oriented Architecture (SOA) dan Prototipe

\section{MATERIAL DAN METODE}

\subsection{Material}

\section{a. Web Service}

Web services adalah suatu system perangkat lunak yang didisain untuk mendukung interaksi mesin ke mesin pada suatu jaringan. Ia mempunyai suatu interface yang diuraikan dalam suatu format machine-processible seperti WSDL (Web Service Description Language). Sistem lain yang berinteraksi dengan Web service dilakukan melalui interface/antar muka menggunakan pesan seperti pada SOAP. Pada umumnya pesan ini melalui HTTP dan XML yang merupakan salah satu standard web.

\section{b. Test of English for International Communication (TOEIC)}

TOEIC (Test of English for International Communication) adalah tes mengukur kemampuan berbahasa Inggris untuk mereka yang bahasa sehari-harinya bukan bahasa Inggris. Tes TOEIC mengukur kemampuan bahasa Inggris untuk individu yang sedang belajar atau bekerja dilingkungan global. Skor TOEIC menunjukkan seberapa baik seseorang dapat berkomunikasi 
dalam bahasa Inggris dalam dunia pendidikan, bisnis, perdagangan dan industri. Tes ini tidak memerlukan pengetahuan atau istilah khusus selain dari bahasa Inggris yang dipergunakan sehari-hari.

TOEIC mengukur secara objektif dan akurat mengenai kemampuan berkomunikasi seseorang dalam bahasa Inggris. Tes ini dirancang berdasarkan kondisi sehari-hari yang dijalani setiap orang sehingga tes ini sangat mudah dipahami dan dirasakan langsung manfaatnya karena berkaitan langsung dengan kehidupan sehari-hari yang dialami setiap orang di lingkungannya.

\subsection{Metode}

Pengembangan web service digital assessment TOEIC menggunakan pendekatan Service Oriented Architecture (SOA). SOA adalah metode yang mengintegrasikan proses bisnis dengan standarisasi komponen yang dapat digunakan kembali dalam proses bisnis yang berubah-ubah. Sedangkan dalam pengembangan aplikasi sendiri menggunakan metode prototipe karena akan memudahkan dalam menggali kebutuhan sistem dengan pengguna. Tahap-tahap penelitian SOA-Prototype disajikan pada Gambar 1.

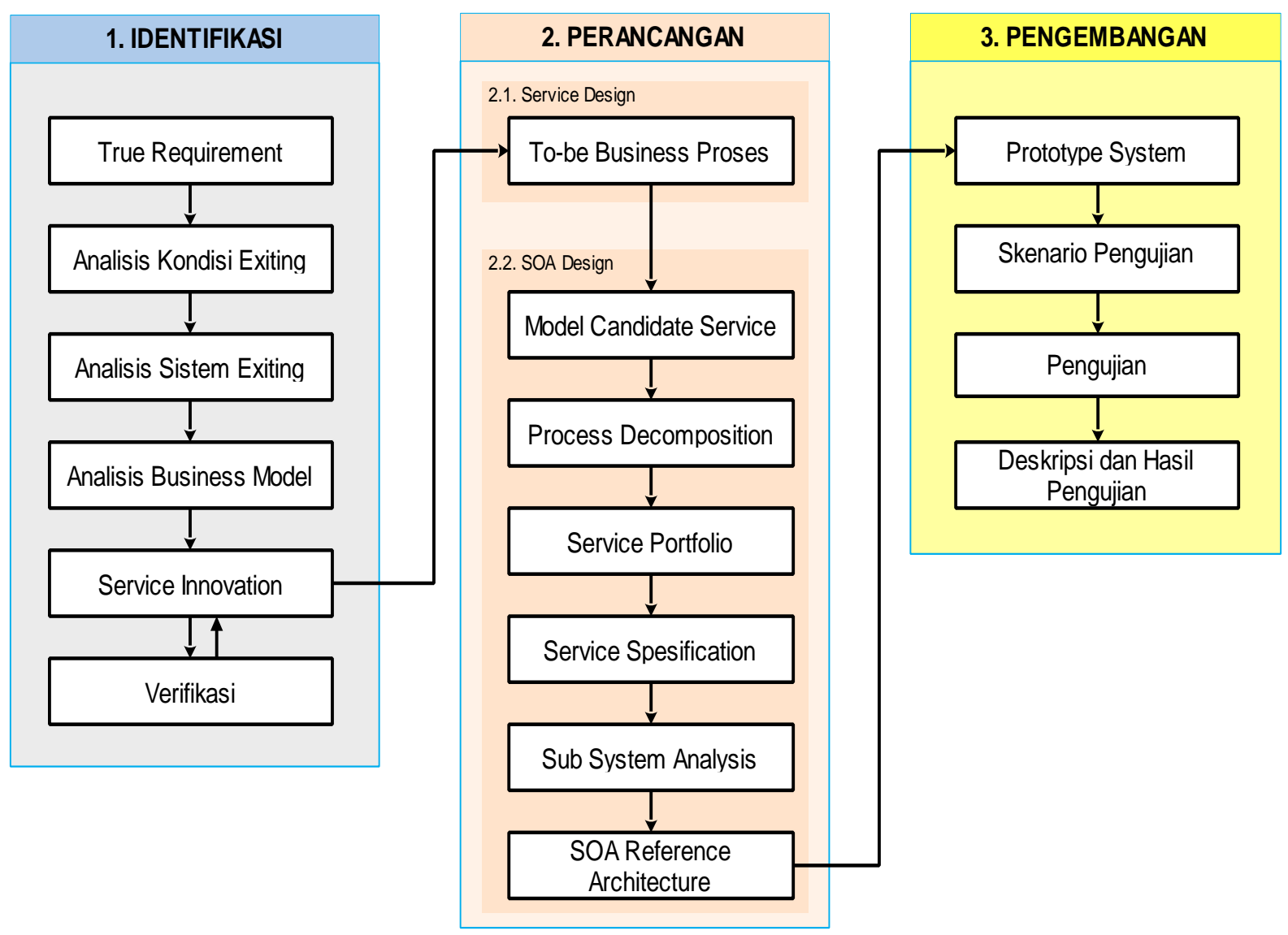

Gambar 1. Kerangka Penelitian SOA-Prototype 
Langkah-langkah pada tahap identifikasi yaitu

a. True Requirement dilakukan dengan wawancara dan observasi pelaksanaan ujian TOEIC sehingga didapatkan daftar permasalahan, daftar arahan dan daftar solusi untuk menyelesaikan masalah

b. Analisis kondisi saat ini dilakukan dengan menganalisis jenis layanan dan proses yang dijalankan pada pelaksanaan ujian TOEIC sehingga dihasilkan daftar layanan yang harus tersedia berdasarkan daftar solusi di tahap sebelumnya

c. Analisis sistem yang sudah ada pada pelaksanaan ujian TOEIC sebagai dasar pemgembangan sistem usulan.

d. Memetakan proses bisnis pada pelaksanaan assessment TOEIC

e. Menyusun inovasi layanan yang dikembangkan untuk pelaksanaan assessment TOEIC secara digital yang terintegrasi

f. Verifikasi innovasi layanan dengan melibatkan lembaga bahasa yang ada di kota Surakarta Langkah-langkah pada tahap pengembangan terdiri dari dua tahap yaitu tahap Service Design yang digunakan untuk mendapatkan gambaran umum dan gambaran detail pada inovasi layanan yang dikembangan. Kemudian tahap SOA Design digunakan untuk mendapatkan arsistektur sistem dari inovasi layanan yang dikembangkan dengan langkah-langkah sebagai berikut.

a. Identifikasi model Candidate Service untuk menentukan tujuan dan proses layanan yang tercakup pada pelaksanaan assessment TOEIC

b. Perancangan process decomposition untuk menggambarkan proses secara spesifik

c. Menyusun Service Portfolio dengan memperhatikan tujuan sistem, layanan dapat digunakan di proses yang berbeda, kelayakan biaya dan waktu serta layanan dapat digunakan kembali di seluruh proses

d. Merancangan Service Specification

e. Menganalisis sub-sistem berdasarkan Service Portfolio dan Service Specification

f. Di akhir tahap dihasilkan SOA Reference Architecture yang merupakan penggabungan perancangan sebelumnya

Langkah-langkah pada tahap pengembangan prototype yaitu

a. Pengembangan prototype menggunakan Framework Laravel untuk pengembangan web service, Webix sebagai user interface dan user experience, Mysql sebagai basidata dan bahasa 
pemrograman C\# untuk aplikasi desktop yang digunakan untuk mengakses web service assessment TOEIC.

b. Skenario dan pelaksanaan pengujian dengan menggunakan metode Beta dan juga melakukan pengujian performance dengan mengukur nilai response time.

\section{HASIL DAN PEMBAHASAN}

\subsection{Identifikasi Masalah}

Berdasarkan hasil observasi dan wawancara telah didapatkan pemetaan proses pada pelaksanaan assessment TOEIC dan inovasi layanan yang dikembangkan. Adapun pemetaan proses yang akan digunakan pada assessment TOEIC berbasis digital disajikan pada Tabel 1.

Tabel 1. Pemetaan Proses Assessment TOEIC

\begin{tabular}{|c|c|}
\hline No & Proses Assessment TOEIC \\
\hline 1 & $\begin{array}{l}\text { Manajemen User } \\
\text { User terdiri dari hak akses super admin, proktor dan peserta }\end{array}$ \\
\hline 2 & $\begin{array}{l}\text { Pengelolaan Group Soal dan Jenis Soal } \\
\text { Group soal pada TOIEC terdiri dari Picture Description, Questions and } \\
\text { Response, Short Conversations, Short Talks, Incomplete Sentences, Text } \\
\text { Completion, Reading Comprehension. Sedangkan jenis soal terdiri dari } \\
\text { text dan audio }\end{array}$ \\
\hline 3 & $\begin{array}{l}\text { Pengelolaan Paket Soal dan Bank Soal } \\
\text { Bank soal disusun dalam paket-paket soal setiap paket memiliki } 200 \text { soal }\end{array}$ \\
\hline 4 & $\begin{array}{l}\text { Pengelolaan Sesi } \\
\text { Sesi digunakan untuk mengatur penjadwalan. Pelaksanaan assessment } \\
\text { TOEIC tidak dapat diakses selama sesi belum dibuat dan belum dibuka }\end{array}$ \\
\hline 5 & $\begin{array}{l}\text { Pengelolaan Data Peserta } \\
\text { Data Peserta meliputi biodata, sesi dan paket soal }\end{array}$ \\
\hline 6 & $\begin{array}{l}\text { Pelaksanaan Assessment } \\
\text { Assessment dilakukan menggunakan aplikasi desktop yang terintegrasi } \\
\text { dengan web service. }\end{array}$ \\
\hline 7 & $\begin{array}{l}\text { Hasil Assessment } \\
\text { Hasil otomatis akan dihitung setelah assessment selesai }\end{array}$ \\
\hline
\end{tabular}

Sedangkan inovasi layanan yang dikembangkan untuk pelaksanaan assessment TOEIC secara digital disajikan pada Tabel 2. 
Tabel 2. Inovasi layanan pada pelaksanaan Assessment TOEIC secara digital

\begin{tabular}{|c|c|c|}
\hline No & Proses & Kebutuhan Inovasi Layanan \\
\hline 1 & Manajemen User & $\begin{array}{l}\text { - Tambah user beserta role, tampil user, ubah user } \\
\text { dan hapus user }\end{array}$ \\
\hline 2 & Pengelolaan Group Soal dan Jenis Soal & $\begin{array}{l}\text { - Tampil group dan jenis soal format tabel } \\
\text { - Tampil group dan jenis soal format combo }\end{array}$ \\
\hline 3 & Pengelolaan Paket Soal dan Bank Soal & $\begin{array}{l}\text { - Tambah, tampil format tabel, tampil format combo, } \\
\text { ubah dan hapus data paket soal } \\
\text { - Tambah, tampil per paket, ubah dan hapus data } \\
\text { soal } \\
\text { - Enripsi dan dekripsi data soal }\end{array}$ \\
\hline 4 & Pengelolaan Sesi & $\begin{array}{l}\text { - Tambah, tampil format tabel, tampil format combo, } \\
\text { ubah dan hapus data sesi }\end{array}$ \\
\hline 5 & Pengelolaan Data Peserta & $\begin{array}{l}\text { - Tambah, tampil per sesi, ubah dan hapus data } \\
\text { peserta } \\
\text { - Ubah sesi peserta } \\
\text { - Reset status ujian peserta menjadi belum ujian } \\
\text { - Tampil peserta sudah ujian }\end{array}$ \\
\hline 6 & Pelaksanaan Assessment TOEIC & $\begin{array}{l}\text { - Login dan simpan token ke aplikasi desktop } \\
\text { - Proktor melakukan sinkronisasi awal untuk } \\
\text { mengunduh data sesi, peserta dan soal } \\
\text { - Soal dimuat di awal setelah peserta melakukan } \\
\text { login dan tombol mulai ujian akan tampil secara } \\
\text { otomatis ketika seluruh soal sudah berhasil dimuat } \\
\text { - Soal akan diacak sesuai kelompoknya } \\
\text { - Waktu ujian berjalan otomatis dan selalu sinkron ke } \\
\text { basisdata setiap menjawab soal. Ketika terjadi } \\
\text { kegagalan hardware atau jaringan maka sisa waktu } \\
\text { tetap sesuai waktu terakhir } \\
\text { - Soal listening akan tampil dan berjalan otomatis. } \\
\text { Setelah audio berhenti peserta diberikan waktu } 10 \\
\text { detik untuk menjawab. Jawaban tersimpan } \\
\text { otomatis ke basis data ketika soal berikutnya } \\
\text { tampil. Peserta tidak diperbolehkan mengakses soal } \\
\text { listening sebelumnya } \\
\text { - Soal reading akan tampil ketika peserta menekan } \\
\text { tombol lanjut. Jawaban tersimpan otomatis ke basis } \\
\text { data ketika soal berikutnya tampil. Peserta } \\
\text { diperbolehkan mengakses soal sebelumnya } \\
\text { ataupun soal berikutnya } \\
\text { - Sesi assessment akan selesai otomatis jika waktu } \\
\text { habis atau peserta secara manual mengakhiri sesi } \\
\text { assessment-nya } \\
\text { - Peserta yang sudah seleseai sesi assessment-nya } \\
\text { tidak dapat membuka kembali sesi assessment-nya } \\
\text { melama assessment berlangsung proktor dapat } \\
\text { status sesi assessment dari masing-masing peserta }\end{array}$ \\
\hline 7 & Hasil Assessment & $\begin{array}{l}\text { - Hitung skor dan simpan ke basis data } \\
\text { - Tampil skor per peserta } \\
\text { - Tampil skor per sesi } \\
\text { - Proktor melakukan sinkronisasi ke server TOEIC }\end{array}$ \\
\hline
\end{tabular}




\subsection{Perancangan Sistem}

Sebagai gambaran sistem yang dikembangkan berikut penulis telah melakukan perancangan sistem service design disajikan pada Gambar 2.

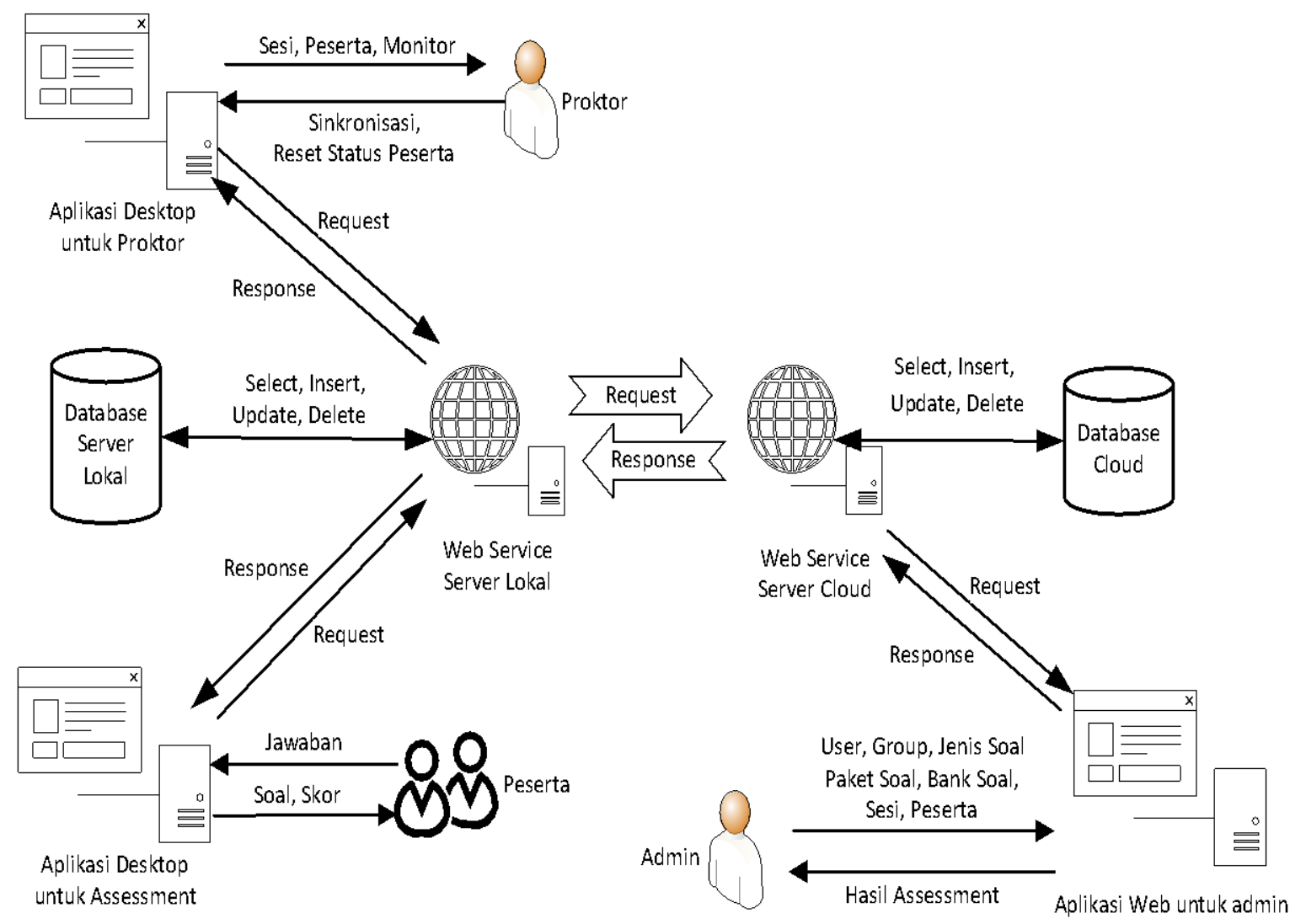

Gambar 2. Service Design Digital Assessment TOEIC

Metode Representative State Transfer (REST) penulis gunakan pada pengembangan web service Digital Assessment TOEIC, dimana REST pada client melakukan request dengan format JavaScript Object Notation (JSON) dan REST pada server menyediakan response resources berupa JavaScript Object Notation (JSON). Komunikasi server dan client melalui URIs (Universal Resource Identifiers).

Terdapat dua basis data yaitu basis data cloud yang digunakan sebagai basis data utama dan bersifat tunggal. Sedangkan basis data lokal merupakan basis data yang ada di tempat pelaksanaan assessment yang bisa lebih dari satu tempat. Basis data cloud menyimpan seluruh data sedangkan basis data lokal hanya menyimpan data sesi, peserta, soal, jawaban dan skor sesuai peserta yang didaftarkan dan hanya bersifat sementara dan akan hilang jika dilakukan sinkronisasi hasil assessment.

Admin memili hak akses untuk mengelola seluruh data. Proktor mempunya hak akses sinkronisasi data awal, monitoring jalannya assessment, reset status peserta dan sinkronisasi hasil 
assessment. Sedangkan peserta mempunyai hak akses soal dan menjawab. Aplikasi client berupa desktop dan menggunakan web service untuk mengakses data dari basis data. Selain service design penulis juga merancang SOA design dengan hasil akhir berupa SOA Reference Architecture disajikan pada Gambar 3.

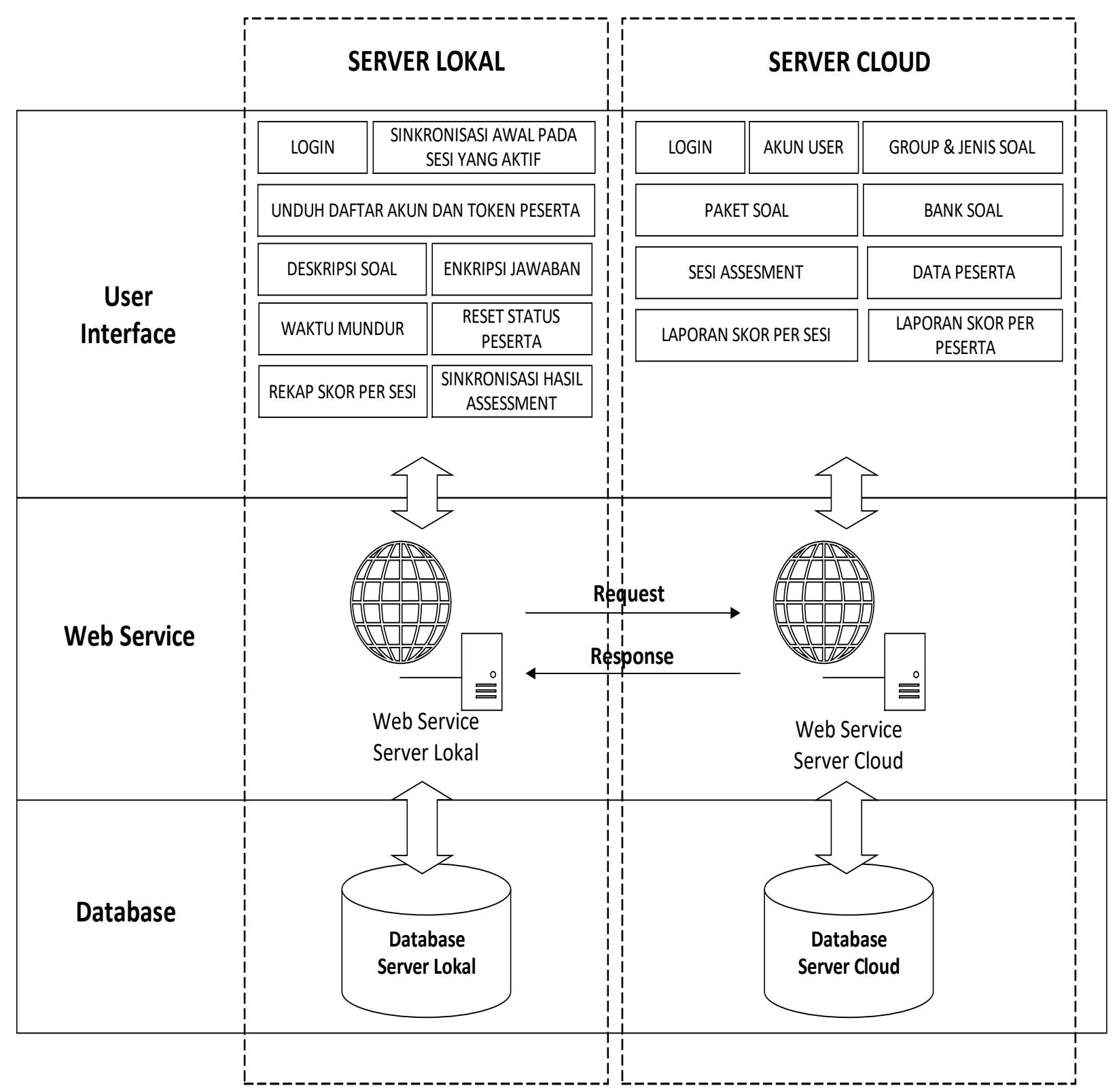

Gambar 3. SOA Reference Architecture Digital Assessment TOEIC

Berdasarkan Gambar 3, seluruh aktifitas transaksi data melalui web service. Adapun struktur JSON yang digunakan sebagai object data pada proses request dan response untuk mengakses soal disajikan pada Tabel 3. 
Tabel 3. Struktur JSON Akses Soal

\begin{tabular}{|c|c|c|}
\hline Service & Request & Response \\
\hline Tampil Soal & $\begin{array}{l}\text { \{ } \\
\text { "no_peserta":"xxxxxx", } \\
\text { "token":"xxxxxxxxxx", } \\
\text { \} }\end{array}$ & 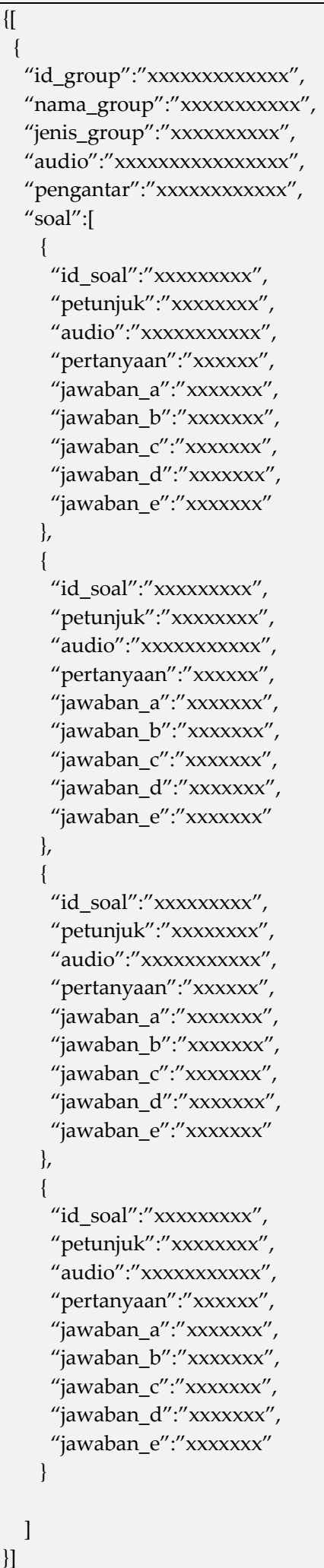 \\
\hline
\end{tabular}




\subsection{Pengembangan Prototype}

User Interface dan User Experience dikembangkan dengan menggunakan Webix Framework yang berbasis bahasa pemrograman Javascript. Tampilan aplikasi yang diakses oleh admin pada master data group dan jenis soal disajikan pada Gambar 4.

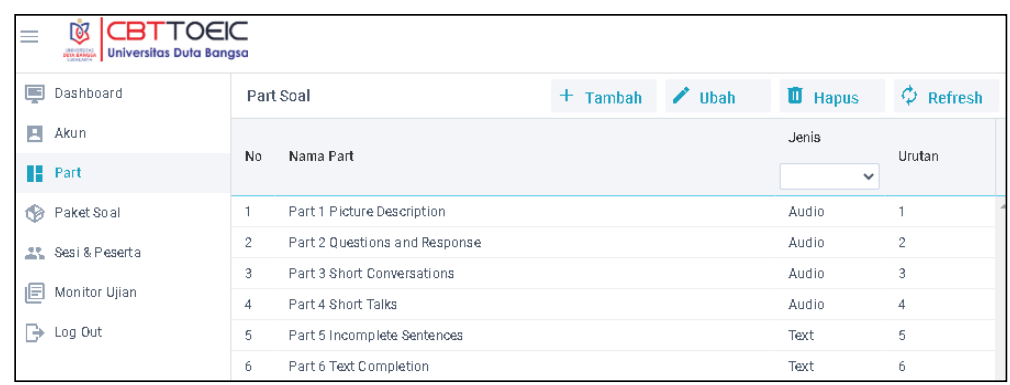

Gambar 4. Master data group dan jenis soal

Tampilan aplikasi yang diakses admin pada form soal dengan jenis audio disajikan pada

\section{Gambar 5.}

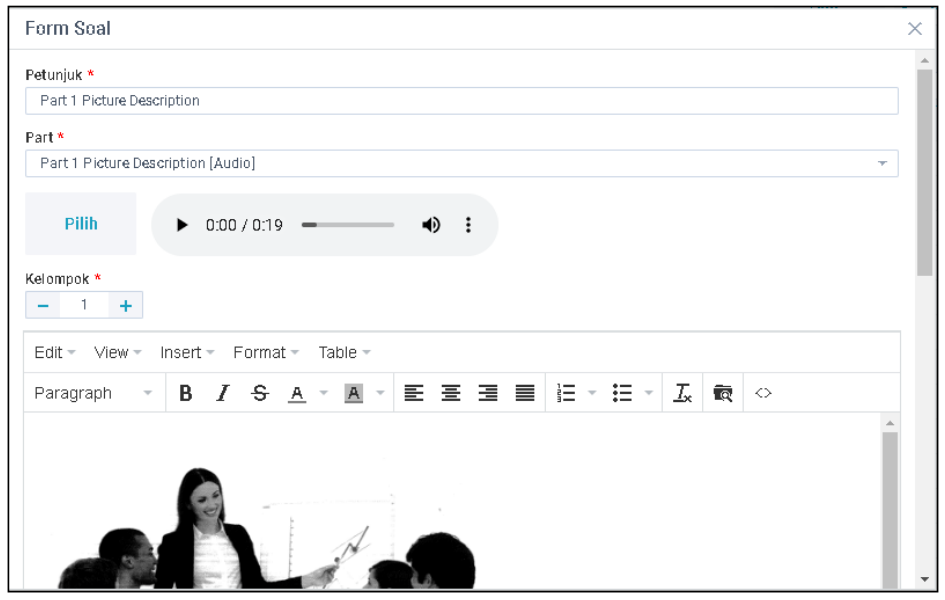

Gambar 5. Form soal dengan jenis audio

Tampilan aplikasi pada hak akses peserta saat proses assessment pada halaman pengantar pada listening test disajikan pada Gambar 6.

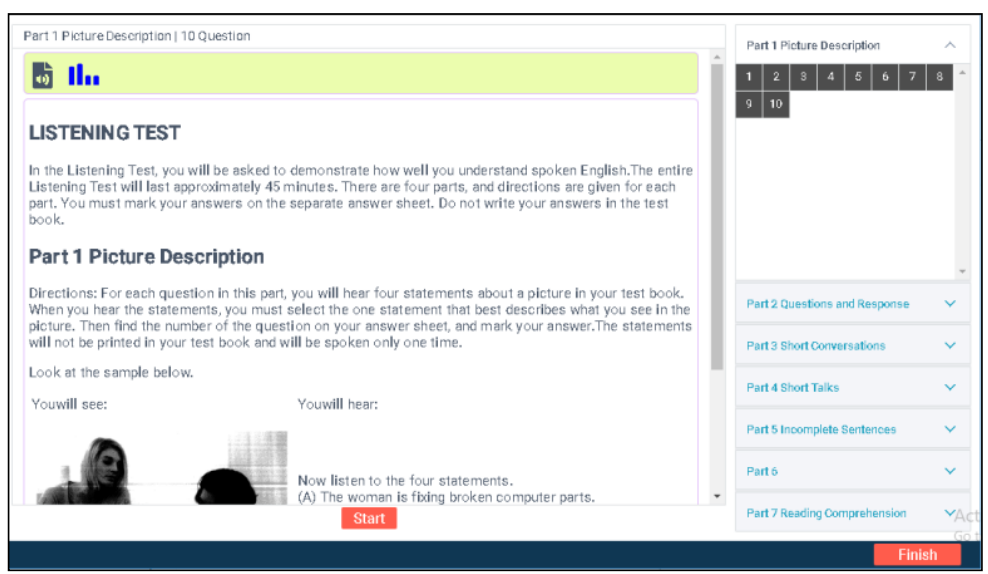

Gambar 6. Halaman pengantar pada listening test 
Tampilan aplikasi yang diakses peserta pada halaman soal listening test disajikan pada Gambar 7.

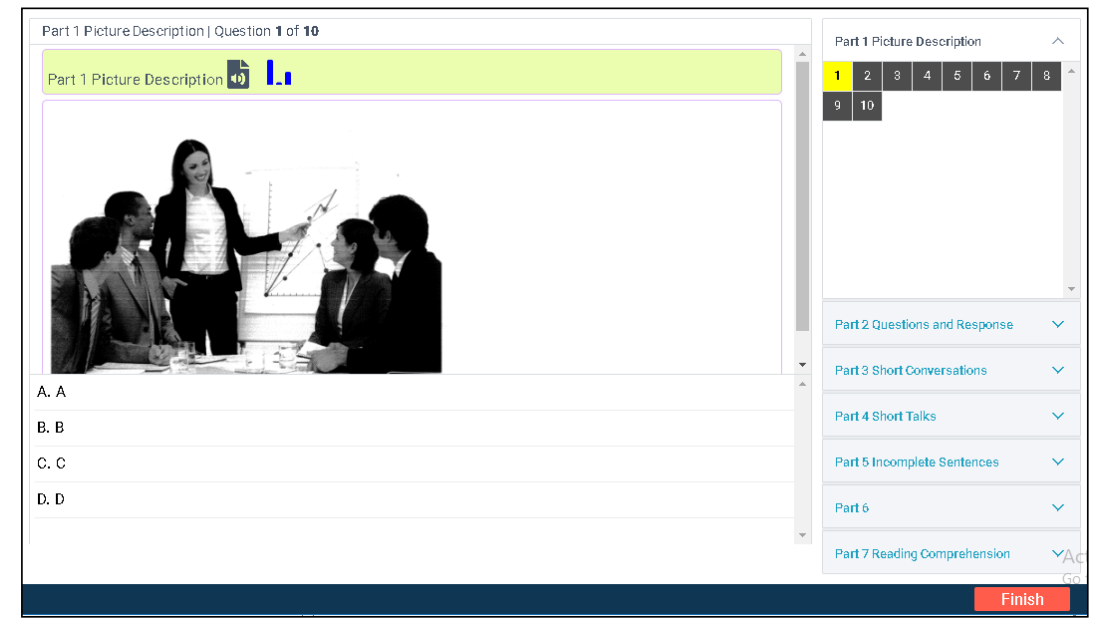

Gambar 7. Halaman soal listening test

Tampilan aplikasi yang diakses peserta pada halaman soal setelah assessment selesai disajikan pada Gambar 8.

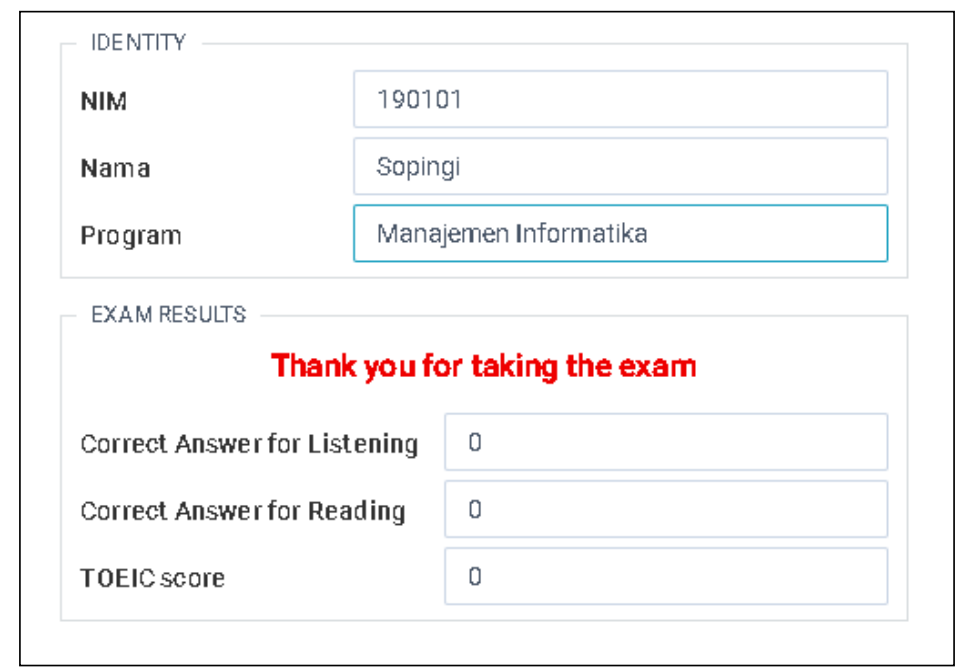

Gambar 8. Halaman skor setelah assessment selesai

Pengujian dilakukan dengan dua tahap. Tahap awal berupa pengujian Beta dengan melibatkan 40 mahasiswa tingkat akhir dan 2 dosen bahasa. Pengujian dengan menggunakan skenario uji terhadap aplikasi menyesuaikan kebutuhan inovasi layanan dan dilaksanakan dalam ruang laboratorium bahasa. Hasil pengujian Beta Digital Assessment TOEIC hak akses proktor yang telah dilakukan disajikan pada Tabel 4. 
Tabel 4. Hasil pengujian Beta Digital Assessment TOEIC hak akses proktor

\begin{tabular}{|c|c|c|c|c|}
\hline No & Pernyataan & Pilihan & Responden & Prosentase \\
\hline \multirow{5}{*}{1} & \multirow{5}{*}{$\begin{array}{l}\text { Sinkronisasi awal } \\
\text { berjalan dengan lancar }\end{array}$} & Sangat Setuju & 2 & $100 \%$ \\
\hline & & Setuju & 0 & $0 \%$ \\
\hline & & Cukup Setuju & 0 & $0 \%$ \\
\hline & & Kurang Setuju & 0 & $0 \%$ \\
\hline & & Tidak Setuju & 0 & $0 \%$ \\
\hline & & Jumlah & 2 & $100 \%$ \\
\hline \multirow{5}{*}{2} & \multirow{5}{*}{$\begin{array}{l}\text { Daftar akun dapat } \\
\text { diunduh dalam format } \\
\text { excel }\end{array}$} & Sangat Setuju & 1 & $50 \%$ \\
\hline & & Setuju & 1 & $50 \%$ \\
\hline & & Cukup Setuju & 0 & $0 \%$ \\
\hline & & Kurang Setuju & 0 & $0 \%$ \\
\hline & & Tidak Setuju & 0 & $0 \%$ \\
\hline & & Jumlah & 2 & $100 \%$ \\
\hline \multirow{5}{*}{3} & \multirow{5}{*}{$\begin{array}{l}\text { Monitoring status peserta, } \\
\text { jumlah soal terjawab dan } \\
\text { waktu siswa terupdate } \\
\text { secara realtime }\end{array}$} & Sangat Setuju & 0 & $0 \%$ \\
\hline & & Setuju & 0 & $0 \%$ \\
\hline & & Cukup Setuju & 1 & $50 \%$ \\
\hline & & Kurang Setuju & 1 & $50 \%$ \\
\hline & & Tidak Setuju & 0 & $0 \%$ \\
\hline & & Jumlah & 2 & $100 \%$ \\
\hline \multirow{5}{*}{4} & \multirow{5}{*}{$\begin{array}{l}\text { Sinkronisasi hasil } \\
\text { assessment berjalan } \\
\text { dengan lancar }\end{array}$} & Sangat Setuju & 0 & $0 \%$ \\
\hline & & Setuju & 2 & $100 \%$ \\
\hline & & Cukup Setuju & 0 & $0 \%$ \\
\hline & & Kurang Setuju & 0 & $0 \%$ \\
\hline & & Tidak Setuju & 0 & $0 \%$ \\
\hline \multicolumn{3}{|r|}{ Jumlah } & 2 & $100 \%$ \\
\hline
\end{tabular}

Berdasarkatn Tabel 4, dilakukan perhitungan dengan menggunakan rumus:

$$
\frac{\text { Jumlah masing }- \text { masing pilihan }}{\text { Jumlah Responden } \times \text { Jumlah Pernyataan }} \times 100 \%
$$

Sangat Setuju : $\frac{3}{8} \times 100 \%=37,5 \%$

Setuju $\quad: \frac{3}{8} \times 100 \%=37,5 \%$

Cukup Setuju : $\frac{1}{8} \times 100 \%=12,5 \%$

Kurang Setuju : $\frac{1}{8} \times 100 \%=12,5 \%$

Tidak Setuju $: \frac{0}{8} \times 100 \%=0 \%$

Hasil pengujian Beta Disgital Assesment TOEIC hak akses peserta disajikan pada Tabel 5. 
Tabel 5. Hasil Pengujian Beta Digital Assessment TOEIC hak akses peserta

\begin{tabular}{|c|c|c|c|c|}
\hline No & Pernyataan & Pilihan & Responden & Prosentase \\
\hline \multirow{6}{*}{1} & \multirow{6}{*}{$\begin{array}{l}\text { Proses login } \\
\text { berjalan lancar }\end{array}$} & Sangat Setuju & 34 & $85 \%$ \\
\hline & & Setuju & 0 & $0 \%$ \\
\hline & & Cukup Setuju & 3 & $8 \%$ \\
\hline & & Kurang Setuju & 2 & $5 \%$ \\
\hline & & Tidak Setuju & 1 & $3 \%$ \\
\hline & & Jumlah & 40 & $100 \%$ \\
\hline \multirow{6}{*}{2} & \multirow{6}{*}{$\begin{array}{l}\text { Soal berhasil } \\
\text { dimuat dan tampil } \\
\text { dengan lancar }\end{array}$} & Sangat Setuju & 32 & $80 \%$ \\
\hline & & Setuju & 1 & $3 \%$ \\
\hline & & Cukup Setuju & 0 & $0 \%$ \\
\hline & & Kurang Setuju & 4 & $10 \%$ \\
\hline & & Tidak Setuju & 3 & $8 \%$ \\
\hline & & Jumlah & 40 & $100 \%$ \\
\hline \multirow{6}{*}{3} & \multirow{6}{*}{$\begin{array}{l}\text { Soal listening } \\
\text { dapat berjalan } \\
\text { dengan lancar }\end{array}$} & Sangat Setuju & 39 & $98 \%$ \\
\hline & & Setuju & 0 & $0 \%$ \\
\hline & & Cukup Setuju & 0 & $0 \%$ \\
\hline & & Kurang Setuju & 1 & $3 \%$ \\
\hline & & Tidak Setuju & 0 & $0 \%$ \\
\hline & & Jumlah & 40 & $100 \%$ \\
\hline \multirow{6}{*}{4} & \multirow{6}{*}{$\begin{array}{l}\text { Soal reading dapat } \\
\text { berjalan dengan } \\
\text { lancar }\end{array}$} & Sangat Setuju & 36 & $90 \%$ \\
\hline & & Setuju & 4 & $10 \%$ \\
\hline & & Cukup Setuju & 0 & $0 \%$ \\
\hline & & Kurang Setuju & 0 & $0 \%$ \\
\hline & & Tidak Setuju & 0 & $0 \%$ \\
\hline & & Jumlah & 40 & $100 \%$ \\
\hline \multirow{6}{*}{5} & \multirow{6}{*}{$\begin{array}{l}\text { Pergantian soal ke } \\
\text { berikutnya } \\
\text { berjalan lancar }\end{array}$} & Sangat Setuju & 40 & $100 \%$ \\
\hline & & Setuju & 0 & $0 \%$ \\
\hline & & Cukup Setuju & 0 & $0 \%$ \\
\hline & & Kurang Setuju & 0 & $0 \%$ \\
\hline & & Tidak Setuju & 0 & $0 \%$ \\
\hline & & Jumlah & 40 & $100 \%$ \\
\hline \multirow{6}{*}{6} & \multirow{6}{*}{$\begin{array}{l}\text { Waktu berjalan } \\
\text { otomatis dan } \\
\text { selesai sesuai } \\
\text { dengan waktu } \\
\text { yang disediakan }\end{array}$} & Sangat Setuju & 40 & $100 \%$ \\
\hline & & Setuju & 0 & $0 \%$ \\
\hline & & Cukup Setuju & 0 & $0 \%$ \\
\hline & & Kurang Setuju & 0 & $0 \%$ \\
\hline & & Tidak Setuju & 0 & $0 \%$ \\
\hline & & Jumlah & 40 & $100 \%$ \\
\hline \multirow{5}{*}{7} & \multirow{5}{*}{$\begin{array}{l}\text { Skor TOEIC tampil } \\
\text { setelah selesai } \\
\text { Assessment }\end{array}$} & Sangat Setuju & 40 & $100 \%$ \\
\hline & & Setuju & 0 & $0 \%$ \\
\hline & & Cukup Setuju & 0 & $0 \%$ \\
\hline & & Kurang Setuju & 0 & $0 \%$ \\
\hline & & Tidak Setuju & 0 & $0 \%$ \\
\hline & & Jumlah & 40 & $100 \%$ \\
\hline
\end{tabular}


Hasil pengujian Tabel 5 dapat dilakukan perhitungan sebagai berikut

Sangat Setuju : $\frac{261}{280} \times 100 \%=93.21 \%$

Setuju

$$
: \frac{5}{280} \times 100 \%=1.79 \%
$$

Cukup Setuju : $\frac{3}{280} \times 100 \%=1.07 \%$

Kurang Setuju : $\frac{7}{280} \times 100 \%=2.50 \%$

Tidak Setuju $: \frac{4}{280} \times 100 \%=1.43 \%$

Pengujian tahap kedua adalah menguji performance terhadap web service yang sudah dikembangkan dengan mengukur nilai response time menggunakan aplikasi JMeter dengan jumlah thread 100 user dalam waktu 20 detik. Response time adalah waktu yang dibutuhkan dalam pengantaran data dari pengirim ke penerima. Hasil pengukuran nilai response time disajikan pada

\section{Gambar 9.}

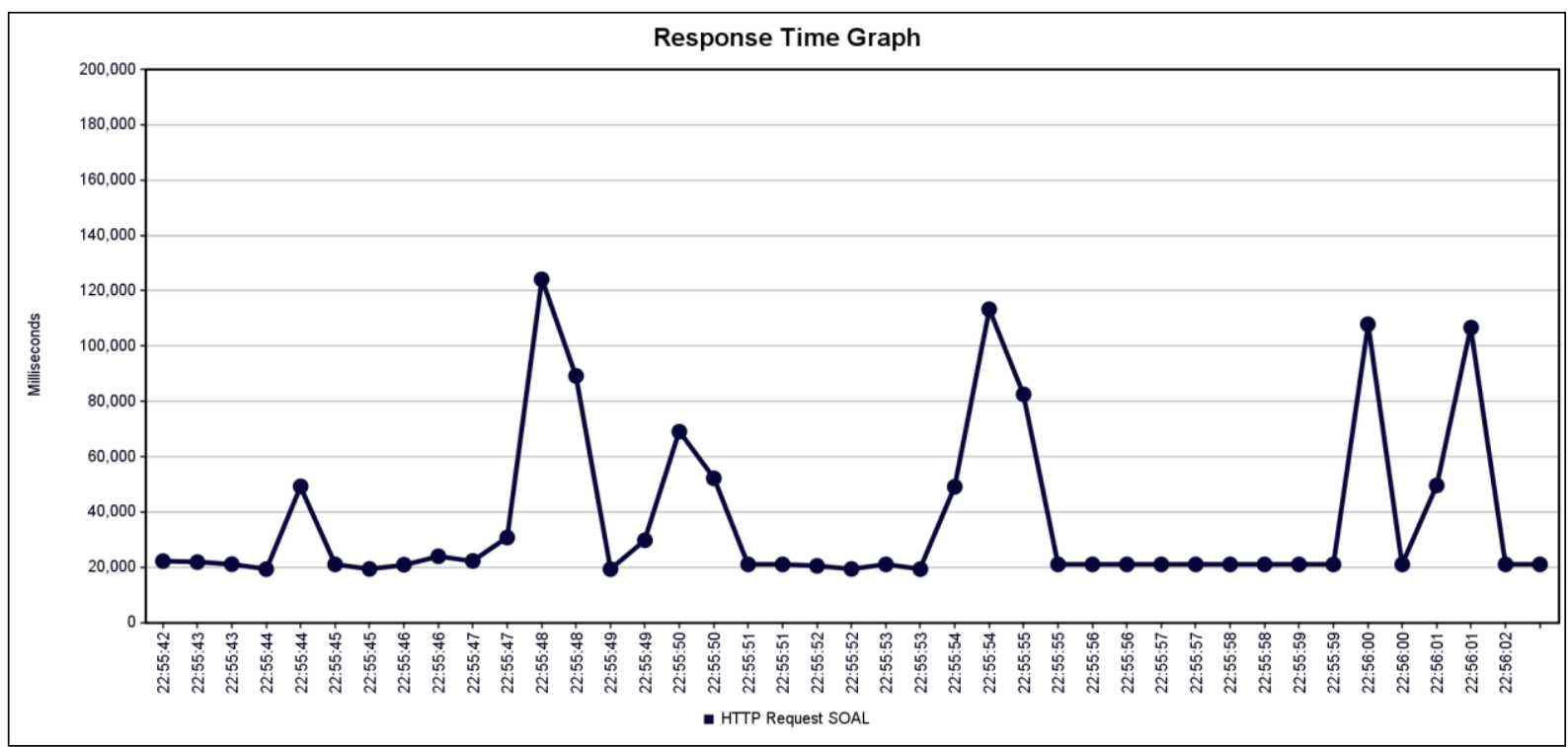

Gambar 9. Pengujian Response Time pada pengambilam data soal

\section{KESIMPULAN}

Penggunaan web service dalam komunikasi data antara aplikasi database dengan aplikasi client membuat aplikasi Digital Assessment TOEIC layak digunakan sebagai aplikasi production, terbukti bahwa hasil pengujian beta menunjukan nilai "sangat setuju" dan "setuju" memiliki prosentase yang tinggi serta pengujian performance memiliki nilai response time paling lama adalah 120 ms ketika dilakukan thread 100 user dalam waktu 30 detik. Meskipun dalam pengujian beta masih ditemukan nilai yang kurang karena terpengaruh kondisi hardware dan jaringan pada saat pengujian. 
Peneliti berikutnya bisa membahas terkait permasalahan kualitas layanan atau Qos (Quality of service) pada web service yang meliputi accessibility, reliability dan performance.

\section{REFERENSI}

[1] L. D. Prasojo, Perancangan Database Sistem Informasi Manajemen Pendidikan dengan DBMS Microsoft (Access dan SQL Server). Yogyakarta: UNY Press, 2014.

[2] R. Sturm, C. Pollard, and J. Craig, Application Performance Management (APM) in the Digital Enterprise. Morgan Kaufmann, 2017.

[3] D. P. Pratama, M. A. Pasha, Mardiyono, and L. Triyono, “SIMTIC: Sistem Informasi Manajemen Tes TOEIC," J. Tek. Elektro Terap., vol. 8, no. 1, pp. 16-23, 2019.

[4] R. Wakhidah, M. F. Maftuh, and E. Maaliah, “Pengembangan Aplikasi Listening Test Berbasis Android," JOIC, vol. 3, no. 2, pp. 47-53, 2019.

[5] Y. F. Chandra, N. Dwiyani, and Y. Huda, “Perancangan Aplikasi Mobile Learning Test of English for International Communication (TOEIC) Simulation Pada Smartphone Berbasis Android," Vokasional Tek. Elektron., vol. 2, no. 1, pp. 167-175, 2016.

[6] M. B. Juric, R. Loganathan, P. Sarang, and F. Jennings, SOA Approach to Integration. Birmingham: Packt Publishing, 2008.

[7] Sopingi and Nurchim, “Model Integrasi Data Akademik Perguruam TInggi dengan Memanfaatkan Web Service dan Proxy Object," 2017. 